\title{
Tragic Heroines and Wise Women in the Novels of Somerville and Ross
}

\author{
By Angela Ryan \\ University College, Cork
}

\begin{abstract}
Copyright (c) 2005 by Angela Ryan. This text may be archived and redistributed in electronic form, provided that the author and journal are properly cited and no fee is charged for access. Archiving, redistribution, or republication of this text on other terms, in any medium, requires the notification of the journal and consent of the author.
\end{abstract}

\begin{abstract}
The novels of Somerville and Ross depict, behind their wit and social satire, a darker tragic vision in which class and gender overdetermine the outcomes often awaiting female characters. Even the heroines of relatively privileged background are vulnerable to change and insecurity. In The Real Charlotte the eponymous heroine's intelligence and determination fail to guard her against the predicament of the 'unmarriageable' woman in the society of the period. Her strength of character, her capacity to foresee and influence events (like the archaic Irish or Greek Wise Woman figure) turn to despair and damage to others. In The Silver Fox the outcomes are happier for the two heroines through the agency of another pre-Olympian tragic Wise Woman, herself the victim of tragic fate. In Sarah's Youth, a notable example of Modernism in Irish writing, the Wise Woman figures are the heroine's half-sister, and an older mentor-figure. Tragedy, engendered in the conflictual social-family nexus, is averted through the agency of foreknowledge, and a certain relative modernisation of society's attitudes to (economically independent) women.
\end{abstract}

Key Words: Tragic heroine, Somerville \& Ross, Irish fiction in English, Women's studies, Antoine Compagnon, Aristotle's Poetics, Declan Kiberd, Julia Kristeva.

Aristotle's model of tragedy in the Poetics encompasses a number of concepts which this study uses as hermeneutic strategies for the fictional writings of Somerville and Ross. Writing in the fourth century BCE, Aristotle described Attic tragedy of the fifth century BCE as engaging the function of mimesis, representation, to achieve catharsis, an imaginative identification with the hero and the heroic predicament, and purgation, or released affect, when the hero achieves self-knowledge - anagnoresis - consequent upon catastrophe. Freud was later to use these ideas to describe the therapeutic effect of the encounter, in psychoanalysis, of two discourses, one governed

ISSN 1699-311X by free association and the other by floating attention; for our purposes, the material point is the origin of this praxis in the praxis of theatre and the genre of tragedy.

estin oun tragôidia mimêsis praxeôs spoudaias kai teleias megethos echousês, hêdusmenôi logôi chôris hekastôi tôn eidôn en tois moriois, drôntôn kai ou di' apangelias, di' eleou kai phobou perainousa tên tôn toioutôn pathêmatôn katharsin. [[20] Tragedy is, then, a representation of an action that is heroic and complete and of a certain magnitude-by means of language enriched with all kinds of ornament, each used separately in the different parts of the play: it represents men in action and does not use narrative, and through pity and fear it effects relief to these and similar emotions. (Aristotle 1932 : 1449b) 
This displacement of narrative in favour of action might seem to displace fiction from the tragic vision. However, while I am not saying the catharsis Somerville and Ross' novels might enable in the reader is exactly similar to Aristotelian catharsis, my readings of these novels nonetheless tend to indicate a certain tragic vision, and in particular an engagement of tragic rhetoric. Stylistic elements refer to an early-tragic, or pre-tragic (that is pre-Olympian) cosmogony, related to ancient epic. Frequent references in the works of Somerville and Ross to folk and ancient Irish culture bear out this idea of the presence of the epic as a literary source, whilst adding resonance to the referential use of the tragic as the theatre of encounter between the epic and the contemporary - as was the case in fifth-century Athens, and arguably in seventeenth-century France (Ryan: 2004a).

Classical tragedy evolved as the dramatic inscription of older mythic and epic content: in the case of Somerville and Ross, there is reference both to this content, at the origin of western literature (and recurring today in popular culture) and also to Irish mythology. As for catharsis itself, there remains the question as to whether it is a function of the heroine as of the hero. I have argued elsewhere that the heroine of tragedy, Anglo-Irish tragedy (Ryan 1992), and also tragedy in general (Ryan 1994; 2003), may not have the same possibility of enabling catharsis as the hero, because of reduced potential for representation and also because of constraints on the body of the heroine as a representational mode. Typically she does not act, or cannot move, or is under the governance of another. Recent developments in women's writing and in the representation of women in writing have done much to change this. However this restriction in representational form is not to diminish her importance for the tragic imaginaire, though female representation needs to be read with respect to difference.

Three further aspects of the Aristotelian tragic model, in addition to mimesis and catharsis, are: hubris (tragic excess, lack of measure or judgement), hamartia (tragic misstep or error) and anagnoresis (self-knowledge as a consequence of the tragic catastrophe). Hubris is not, on the whole, a characteristic of heroines, but is so to some extent in Somerville and
Ross's work. Many of their heroines are strongminded and forceful, and evoke resentment by being lively and active. This is largely balanced by their immense vulnerability in a society where marriage is the only respectable status for a woman, where all efforts must go to achieving it, and not doing so is to be humiliated for the rest of one's life. This applies somewhat less to the heroine of the later Sarah's Youth (Somerville 1938), though even there, financial independence is a factor (as it was, of course, for Lucy in The Real Charlotte (Somerville \& Ross 1894) and for Lady Susan in The Silver Fox (Somerville \& Ross 1904), though without the result constituting anything like equal access to autonomy of action). Charlotte's personal tragedy is that the man she loves, who did express love for her, married another, and noone else has wanted to marry her. This is a social, more than an emotional reality in this period, where marriage is a dynastic and an economic matter, not simply an affective process. The anti-heroic Roddy Lambert is considered to be socially acceptable because he is the agent of the Dysart family, the local major landowners; Charlotte remains an untouchable, given some independence by the acquisition of some relative prosperity - at the price of miserliness - and the cultivation of her mind and wit by reading.

Hamartia, the hero's tragic misstep, and anagnoresis, the moment of self-knowledge achieved after catastrophe and suffering, when the hero learns who he is and what his life has been for, are certainly present in the three novels studied here, The Real Charlotte, The Silver Fox and Sarah's Youth. The tragic weight of The Real Charlotte is alleviated in the other two novels by wit and irony, and the process of learning is in them less catastrophic for the hero or heroine - though always catastrophic for someone. In The Real Charlotte wit and irony are used by Charlotte herself, and by the two Dysarts Christopher and Pamela, two clever people isolated in an anti-intellectual society. The narrator's voice is often ironic, as well as tragic, and also satirical in its exposing of moeurs —of stupidity and pretentiousness, of moral isolation and empty lives. Without confusing the author and the book, it is pertinent that Somerville and Ross were also isolated 
morally and intellectually; though many of their entourage were clever and lively people, they still used, like Jane Austen's Emma, wit and invention to cover the relative isolation of their situation, in a society where constraints on women affected even those from privileged families.

Even in the comic writing of the R.M. series, which brought fame to Somerville and Ross, tragedy is a constant background presence. In other and darker fiction, such as the three novels in question here, tragic irony is not only a more significant narratological and stylistical presence, but invests the écriture itself, for example in the modes of inscription of the female body. Somerville and Ross's psychology of human tragedy gives point to their witty observation of the minutia of social interaction, and establishes these novels firmly in a European tradition. When Declan Kiberd singled out The Silver Fox for special mention in his account of Irish literature, he marked a transition towards Modernism in the reception, as well as the production, of Irish literature written in English (Kiberd 1995: 27 and passim.).

Somerville and Ross were cousins: Dr. Edith Oenone Somerville (1858-1949) and Violet Florence Martin, whose pen-name was Martin Ross (1862-1915) were leaders of the turn of the century literary movement in Ireland, and leaders for women in society. Somerville was born on Corfu, a child of the family of Castletownshend, a southwest Cork seacoast village dominated by four or five Anglo-Irish Big House families and their extensive social life. Ross, Violet Martin, was born at Ross House in Galway, adopting in 1889 the pseudonym of Martin Ross for general use, since Somerville referred to her cousin and friend as 'Martin'. Edith and Martin met on January 17, 1886 at Castletownshend, fourteen years after Martin and her mother moved to Dublin from Galway, when Martin's father died and her brother, succeeding to the estate, closed their Big House and moved to London, leaving his mother and younger siblings to fend for themselves in tough times. This change in fortune affected both Edith and Martin; their meeting began a lifelong journey of culture, society and literature. Their collaboration was pursued with An Irish Cousin in 1889. In 1894,
The Real Charlotte was published: this novel, comparable to Balzac's La Cousine Bette, is usually considered their masterpiece. The Irish R.M. series: Some Experiences of an Irish R.M.(1899), Further Experiences of an Irish R.M.(1908) and finally In Mr. Knox's Country (1915) are a series of satirical tales set in 1895: an Englishman of Irish descent moves to SouthWest Ireland to take up a post as magistrate, and struggles in his post with a new culture, new neighbors and local politics. It was around this time that Somerville became the first woman Master of Foxhounds in the world, as M.F.H. of the West Carberry Fox Hounds - one example of her leading the way for women. In 1913 she was elected president of the Munster Woman's Franchise League, with Martin as vice-president.

Numerous works were published by the two before Martin Ross's death in 1915 at the age of 53. After Martin's death, Edith continued to write, believing that Martin continued to write with her and putting Martin's name as co-author. Somerville continued working past her ninetieth birthday, when she was celebrated by a BBC talk about their works. She died on October 8, 1949 in Castletownshend at 91. Much of their work discussed the "Ascendancy" class, the traditions and customs of this neo-aristocratic society. However, her portraits of human types, her analysis of human psychology go far beyond the novel as social anthropology: characteristic traits are in the nuances of the quotidian, the delicate details of human interaction. The combination in her paintings of a Frenchinspired social realism, together with a delicate genre-painting sympathy with the observed subject, features also in her fiction. The interculture of Ireland and England is much more complex and subtle than most of the stage and screen adaptations have represented.

The Real Charlotte might with reason be considered their most important work: Terence de Vere White says "Leaving the huge whale Ulysses - basking off-shore, what better Irish novel is there than The Real Charlotte?" (de Vere White: $4^{\text {th }}$ cover). The eponymous Charlotte Mullen is twice spurned by the man she loves, once for Lucy who is made marriageable by the dowry Charlotte does not have, and then again, when Lucy dies, for a woman with the prettiness Charlotte does not 
have, even though she is without money. Ironically and tragically, Charlotte is now an owner of property - which was the reason she was slighted before, since Lambert showed affection for her at that time before marrying Lucy. She takes revenge, by loaning him money, waiting till he gets into financial difficulties and then refusing to help him. Her revenge is tragically transformed into epic disaster, however, when, as a consequence of these events, her cousin Frankie, Lambert's new wife and Charlotte's rival or counter-heroine, is tragically killed. Frankie is thrown from her frightened horse by the Irish Cry, or funeral keening, which, again ironically, is being made over the coffin of Julia Duffy, the woman whom Charlotte replaced as tenant in her new property. Significantly, Charlotte's share in this tragic outcome is a mirror of the events by which she is not innocent of the death of her first rival Lucy:

The real Charlotte had seldom been nearer the surface than at this moment; and Mrs Lambert cowered before the manifestation. [...]

Mrs Lambert leaned back, and her hands fell into her lap.

'Well, thank God there's no harm in that, Charlotte," she said, closing her eyes with a sigh that might have been relief, though her voice sounded a little dreamy and bewildered.

'Ah, you began at the wrong end,' said Charlotte, little attentive to either sigh or tone, "that was written five years ago. Here, what's in this?' She indicated the one lowest in the packet.

Mrs Lambert opened her eyes.

'The drops!' she said with sudden energy, 'on the sideboard - oh, save me -!"

Her voice fainted away, her eyes closed, and her head fell limply on her shoulder. Charlotte sprang instinctively towards the sideboard, but suddenly stopped and looked from Mrs Lambert to the bundle of letters. She caught it up, and plucking out a couple of the most recent, read them through with astonishing speed. She was going to take out another when a slight movement from her companion made her throw them down. [...] Through the keen and crowding contingencies of the moment acme a sound from outside, a well-known voice whistling to a dog, and in the same instant Charlotte had left Mrs Lambert and was deftly and swiftly replacing letters and photographs in the dispatch box [...] Then, with a quickness almost incredible in one of her build, she got the drops from the sideboard, poured them out, and, on her way back to the inert figure on the floor, rang the bell violently. (Somerville \& Ross 1894: vol. II, 238-249)

If in The Real Charlotte it is the young counter-heroine Fanny who is sacrificed, both her husband's and Charlotte's lives are blighted also. However Charlotte's own tragic fate is linked to her female condition, over-determined by the female body and its expected attractiveness to the male gaze. Whilst Lambert's agency for the Dysart estate determined his social status, marriage is the only status marker available to women. Charlotte cannot achieve either: her looks disbar her from marriage status and her sex from career status. This although her actual business sense is great: her father was a land agent, and she helped Lambert unofficially in the office, very effectively, but Lambert, as a man, got the post and the social standing that goes with it. Charlotte had accepted Lambert's marrying Lucy to achieve financial security, but retained a close relationship with him and assumed that Lucy's frail health would one day make him free to marry herself: "[...] 'he talks about her in his sleep!' she quavered out, and began to cry miserably. Charlotte sat perfectly still, looking at Mrs Lambert with eyes that saw, but held no pity for, her abundant tears. How far more serious was this thing, if true, to her, than to that contemptible whining creature [...]" (vol. II 186)

However when Lucy died Lambert married Francie, who is pretty and poor. Nothing that Charlotte can do through talent, ambition, work and self-sacrifice gives her the power that Fanny has through beauty, Lucy through money or Pamela through aristocratic birth, nor that which Lambert acquires by profession. She is doubly overdetermined in her heroinic predicament. To the plain, poor Charlotte the plain rich Lucy is first preferred; then the pretty, poor Francie. Charlotte has become relatively prosperous through her own efforts, where Lucy and Pamela have inherited wealth: but desirability eludes her still for reasons over which she has no possibility of action. Anagnoresis is disabled, 
since the lessons experience is teaching her are those of the limitations on women, unrelated to her moral selfhood. The 'real Charlotte' is never given tragic space, and the illustration of this in the following passage is a rare demonstration of this predicament of the heroine:

It is hard to ask pity for Charlotte, whose many evil qualities have without pity been set down, but the seal of ignoble tragedy had been set on her life; she had not asked for love, but it had come to her, twisted to burlesque by the malign hand of fate. There is pathos as well as humiliation in the thought that such a thing as a soul can be stunted by the trivialities of personal appearance, and it is a fact not beyond the reach of sympathy that each time Charlotte stood before her glass her ugliness spoke to her of failure, and goaded her to revenge. (vol. III 125).

At the same time, she does have the gift of knowledge, and the ability to cause events to happen. It is as if her tragic role is Teiresias: gifted with knowledge but disabled from heroic action. This particular tragic agency is part of her representation, referred to as peasant instinct, but also as archetypal wisdom. This quality of tragic foreknowledge is also present in the character of Norry the Boat, Charlotte's domestic, who realizes before others what is the real Charlotte's ambition and quest:

'For the love o' God, woman!' she whispered, 'is it Miss Francie?'

'Now ye have it,' said Mary Halloran.

Norry clasped her hands, poker and all, and raised them in front of her face, while her eyes apparently communed with a familiar spirit at the other end of the kitchen." (vol. III 100)

Some elements of this tragic world are Irish and semiotically linked to land, dispossession and the female condition. Some are universal and Aristotelian, displaying the connection between Aristotle's vision of the moral dimension of tragedy, and the personhood of the ethical. The ending is a moment of possible anagnoresis, though this is left open: the novel ends on Norry hiding her eyes, like the Fates, from catastrophe, in an atavistic self-blinding

'Miss Francie's killed, her neck's broke below on the road! O God of Heaven, help us!'
Neither Charlotte nor Lambert heard clearly what she said, but the shapeless terror of calamity came about them like a vapour and blanched the hatred in their faces. [...] As she [Norry] saw Lambert, her strength seemed to go from her. She staggered back, and, clutching at the door for support, turned from him and hid her face in her cloak. (vol. III 268)

Other passages abound in direct and stylistic references to sight, blinding and the mind's apprehension of catastrophe: the character's after-lives are left unspoken. Literature is repetition and difference: Julia Kristeva reminds us that all texts are inscribed in intertextuality (Kristeva 1974), and Antoine Compagnon reminds us that texts gloss each other (Compagnon 1979: 35): "Car si l'écriture est toujours une récriture, de subtils mécanismes de régulation, variables selon les époques, oeuvrent pour qu'elle ne soit pas simplement un recopiage, mais une traduction, une citation." [For if writing is always rewriting, there are subtle regulatory mechanisms which vary over time and go to make sure it is not simply copying, but translation, citation.]

Compagnon also speaks of tragedy as a mise en cité: the idea being that the epic and mythic hero is too entropic and too forceful in the newly-developing polis, being out of measure with democratic civilized society, and so tragedy attempts to deal, by representation in a public forum, with the resulting conflicts of ethos between individual and group (Compagnon 1993: 41). Charlotte might thus be seen as a modern version of the entropically forceful heroine, one whose social milieu does not allow space for her gifts and strengths. This would explain the evolution of the 'real' or dark aspects of her nature, and her failed attempt to reconcile her legitimate wish for power with the social givens of her situation.

The Silver Fox is not a novel which has been widely quoted in the scholarship of Irish fiction. There is a certain history of the marginalisation, in the context of the history of national identity, of writers like Somerville, Elizabeth Bowen, or Robert Graves who do not conform to a De Valera-type cultural mindset. Perhaps there is also a tendency to dismiss women writes more easily. The combination of the two has perhaps, 
at least for a period, lessened attention to Somerville, marginalized by combined gender, politics and class. A comparable form of social 'uppityness', recoverable by contemporary feminism as necessary assertiveness, but perceived as hubris in the text, is shown in this novel by its heroine Lady Susan, who is full of life and energy: flirtatious, loud-voiced, confident, a fearless rider, slow to recognize that her equally horse-mad husband has lost his nerve following an accident. She later makes a serious error of judgement, leading to the death of her horse and her own narrow survival. Hubris and hamartia are also displayed by the antihero Mr. Glasgow, in this passage about to leave Ireland having failed in his railway contract:

He [...] looked around the yard at the miscellaneous collection of wreckage from his railway contact [...[ and said to himself that the luck had been against him. It did not occur to him that he had shouldered his competitors out of the market by a tender that left no margin for mistakes. Mr Glasgow never made mistakes, but he had based his brilliant and minute calculations on the theory that the cheap Irish labour would accomplish as much in the day as the costly English, and the fact that it had not done so was obviously beyond the sphere of rational calculation. [...] When he thought of the value of the plant that he was going to leave behind, he scarcely felt like a defaulter: there would be more than enough realized to pay the men, and the Railway Company could afford to lose. There remained to him his private means, the Argentine Republic, his own considerable gifts as an engineer, and -Would Lady Susan remain? He felt little doubt about that part of his future. [...] If there were a weakness in his business dealings, it lay in his determination to be decisive at all points. [...] $\mathrm{Mr}$ Glasgow insisted on this point, and took all risks. (Somerville \& Ross 1904: 177-181)

His ultimate death is tragically linked to fate: “ 'Poor chap,' Hugh went on, 'he was - he met with an accident- I mean, in fact, he's been killed. [...] She turned her head until her eyes were hidden [...] 'It's only - it's so horribleand it makes me think of all that time - and what they said of the bad luck, and everything, "(194-5)
It is Lady Susan who learns, who reaches anagnoresis after hamartia and catastrophe:

She went back to him, and with a shrinking hand moved the inert form and found the letter. As she took it out of the envelope she saw her own name and that of Glasgow; and in one blinding moment read the sentence that connected them. ... Let her not be blamed if her first thought was for herself and her position. Her seven-and-twenty years, her careless and daring flirtations, and her marriage, had not taught her what it was to be in love. She knew that Hugh was in love with her; ... she had no more real comprehension of what he might suffer on her behalf than she had of the flames of hell.... She stood as people stand when the sudden inrush of an idea overwhelms the physical part of them; it had come to her that it might be too late to tell Hughie about it. It sank into her soul ... She bent over him at length ... knowing for the first time the dreadful kiss that is so much to one, so much less than nothing to the other. $(179-182)$

though this is to some extent also true of her husband:

There are junctures in a life when deficiency of intellect may disastrously affect the moral balance, and the smaller mind may have need of supreme and heroic effort to attain the philosophy or even the sanity that is easy to stronger intelligences. [...] Passionate admiration, turning to passionate jealousy of her flawless courage, and self-contempt, and knowledge that his eyes would never again meet hers without consciousness of failure; all these because a good little average man had but two ideas in his life, and when one was taken from him, the other sickened like a poisoned thing. (84-5)

The Silver Fox also has its archaic Wise Woman figure: Slaney, Hugh's cousin, in touch with pre-modern instincts about nature, the pastoral countryside and folk-wisdom:

'I often think,' she said slowly, 'that it isn't much good to go against the country people in these things.'

'I don't agree with you, Miss Morris,' struck in Glasgow. 'I never give in to them. The other day I told one of my fellows to cut down a thorn bush that came in my way surveying. He told me it was a holy thorn, and 
he wouldn't stir it. I just took the bill-hook and cut it down myself.'

Mr Glasgow gave his fair moustache a twist, and looked at Lady Susan. He had a noble gift of self-confidence, and a quietness in manifesting it that made him immediately attractive to lesser intelligences.

'Quite right too,' said Lady Susan, in her strong clear voice, 'that's the way to talk to these people. Why, it's as bad as the Land League, not being allowed to draw one of the nicest coverts in this country, for rubbish of that kind. Hughie, if you don't kill that white fox, I shall think you're in a funk too. You Irish people are all the same. I don't care, $\mathrm{Mr}$ Glasgow and I will take the hounds to Cahirdreen, and we'll have that white brush! I want it awfully to show to the people at home, and tell them I got a witch's brush!'

'You could say it was an evolution of the broomstick,' said Slaney.

Mr Glasgow laughed, and it gave Slaney some satisfaction to see that Lady Susan was bewildered. (54-5)

Reference to the influence over present problems of age-old beliefs and customs is also made by Maria Quin, a local woman who blames Glasgow's railway excavations in sacred ground for the death of her brother, but who nonetheless saves the life of Lady Susan after her hunting accident, whilst believing Lady Susan to be involved in an illicit affair with Glasgow: "She turned and pointed to the tall Druidic stones. [...] 'I thought everyone in the country knew this place. But sure what are you but a stranger!' [...] 'It wasn't wanting to desthroy us ye were, I know that well [...] 'Mind yourself!' she said in a whisper; 'that fellow would throw you on the roadside when he's be tired o' ye.' "'(172-3)

Slaney's own intuitive understanding of native Irish mentalities, inscribed in epic mode, is significantly further increased with knowledge gained through suffering, as is the very purpose of tragedy: "There are moments in life when it is given to some hearts to know their own happiness, and to know it trembling. [...] She knew it with all the tenderness and strong romance that were hidden in her nature, with all the comprehension of herself that had grown out of a bitter experience. [...] as he looked at her he understood [...]" (192). It is ironic that her partner in gained knowledge is Major Bunbury, a most unheroic figure on first appearance, and one who is portrayed as firmly established in the unquestioning stereotypes of gender- and classprivilege: "Major Bunbury was reading a newspaper with that air of serving his country that belongs to men when they read papers. No woman can hope to read the Times as though it were a profession; it is a masculine gift, akin to that of dining." (87). Even here, however, the tragic mode accompanies the ironic: it is suggested that the Major has his own Wise Woman figure, his sister, who, by believing in his more spiritual dimension, has maintained the possibility of its ultimate realization. This adds to the irony of the point that his growing attraction to Slaney is first manifested in the thought that he would like his sister to meet her. Whilst this growth through suffering (tragedy) and through increased self-knowledge (irony) is a factor in the delicate balance of tragedy and irony which enables some form of spiritual growth for Hugh, Susan, Slaney and Bunbury, but is the doom of the Quin family, Glasgow and his wife, it is at the same time contingent upon the societal expectation that women will maintain psychological strength under disadvantageous social conditions. It is this clear demarcation of the unfair social expectations on women that forms the cultural background of the truly tragic ending of The Real Charlotte: it is manifest also in The Silver Fox, not least in the fact that it is the more socially privileged women, Susan and to a lesser degree Slaney, who, unlike Maria Quin, have the best chance at some level of self-determination.

In Sarah's Youth, published in 1938, the eponymous heroine is, by contrast, a modernist. She pursues her love-object, Tim, an ephebe than whom she is taller, richer, more articulate, but whose unfailing kindness has always been important to the underlying vulnerabilities of her situation. The wealth she is to inherit make her the object of various forms of interested pursuit, and this includes the half-occulted hostility of her father, who resents the fact that his dead first wife left her fortune to their daughter and not to him. Sarah's late mother took this step after discovering a secret relationship of her husband's; the daughter of this relationship will later become the wife of Tim, in a further ironic turn of the plot which demonstrates the 
vulnerability of the female condition. Being rich might make women more attractive as marriage objects, but does by no means ensure a truly supportive loving relationship: on the contrary, both Sarah's mother, and Sarah herself are the object of resentment on the part of men for the independence that wealth bestows. The Captain betrays his wife, then resents her leaving her fortune directly to their daughter instead of to himself; Richard's pursuit of Sarah is clearly self-interested. A significant narratological turn occurs when the secret is revealed of Sarah's half-sister Ruth's existence - just as another half-sister, Kathleen, has mystic sensibilities that foresee family events. Here again, women are the bearers of meaning, often secret, often archaic. Sarah is, however, herself represented as active physically, and the symbolism is made clear when she demotes her would-be lover Richard to her man of business, asserting her independence by the stereotypically 'manly' behaviour of lighting a cigarette whilst wearing her riding jodhpurs and seating herself sideways at her desk. Sarah's acquisition of knowledge is represented with irony, whilst making clear reference to tragedy as the theatrical microcosm of human existence and its quest for understanding:

At eighteen pain can be sharp, but in affairs of the spirit it is not often persistent, and Youth's Red Flag of Liberty flaunts again. Sarah's wounds were but moderately deep in fact, it may be questioned if at eighteen summers [...] any wounds are irreparably deep.

She now found herself surveying the drama of life from a new standpoint, and knew that she had to re-set the stage. Tim had made his position perfectly plain. Sarah could not suppress some faint resentment that he had done the job so thoroughly.

Then she laughed, and said aloud:

" "If he be not fair to me, what care I how fair he be!",

and added 'and Tim certainly is fair! Quite a platinum blonde!'

[...] she went on to decide that she would most probably have hated being married.

'All that rot about obeying! The very idea of my obeying Tim! Sister Ruth can do it if she likes!'

[...] And then she told herself that all this thinking was a bore, and she wouldn't bother to think of anything any more. (Somerville 1938: 308-309)

Sarah's Youth is modernist, as is The Silver Fox, to a lesser extent, where The Real Charlotte is not, but all three present active women who behave with some level of tragic hubris or excess. Sarah' youth is deliberately foregrounded as an element in the fact that the novel ends not on loss or death but on irony. Miss Lorimer, Sarah's friend and mentor, and a highly independent woman, is relieved that Sarah has given up her attempt to capture the young and gorgeous Tim, and also failed to be captured by the calculating Richard. She sits smoking — still transgressive for a women, at the time - in the garden of the Greek temple at Taormina in Sicily, as Etna 'smokes' behind her. This is the background both of Greek tragedy and of epic disaster: the irony of the strong independent woman traveller, smoking in public, is all the greater. Tragedy is tamed with Irony, though again, only for women with the good fortune of education and financial independence. Convulsions could always reoccur and trap young lovers; the Fates rather than the Olympians are at work. This is the vision of early tragedy with its Erinnyes, the chtonic women-goddesses of pre-tragic epic. The modern age is nonetheless the theatre of new opportunities for women: Ruth has set herself up in a modest but independent career. At the same time, this is due in part to financial help she got through Sarah's inheritance, as well as to her own initiative and work: the fates are still in balance as to the destiny of the non-privileged heroine.

Returning to Compagnon's point about the epic hero adapting or not to the cultural context of the polis (Compagnon 1993: 41), it is significant that the settings of these tragic-ironic fictions are all rural, whilst being at the same time highly civilized, for the Big House inhabitants, and also rooted in ancient customs, for others. This depiction of those without the walls, and those within the walls of privilege has been interpreted reductively, seeing Somerville and Ross as writers of the Ascendancy, but these three novels show that this is to simplify their representation of the destiny of women. To look at a contemporary example, Roddy Doyle inscribes the urban tragedy of the excluded and 
the less privileged: at the same time, he depicts the special predicament of women, who are often victims, unnameable and therefore ungrievable, in Judith Butler's words: women who 'Walk Into Doors', and whose disrespect, abuse and suffering may not even be named.

In conclusion, it seems arguable that Somerville and Ross, and later Somerville, have a central place both in the history of Irish fiction as a genre, and in the tragic world-view as a mode of expression. They have in the past been assigned too readily to the category of the Big House Ascendancy novel, and certainly the privileged level of education of these women was the prerequisite of women's access to inscription. However, from our contemporary perspective this categorization is reductive, not least because the history of women's full access to authorship is inevitably linked to the history of class divides. Somerville and Ross' use of tragic rhetoric goes beyond turn-of-the-century literary history, and beyond the novel as social document of the Horse Protestant-nationalist divide. At the same time it reflects a European cultural sensibility. Somerville's paintings The Goose Girl and Retrospection portray social difference in the style of French social realism painters, and at the same time with the sensibilities of the reformer and citizen. Somerville's travels, including the time spent in Parisian art studios, is visible in her fiction. If her social position lessened her experience of social pressures on the woman artist and writer, we can only look at the contrast with the tragic fate of the sculptor Camille Claudel, who worked around the same period. The vicissitudes of the painter Patsey in French Leave (Somerville: 1928) are contemporaneous with Claudel and the contrast between the rather contrived happy ending of the fictional painter, and the appalling fate of the real sculptor, serves to point up the forces of tragedy and irony in so many such cases of frustrated talent and success punished by society.

These three novels show that the Aristotelian model of tragedy does operate in their fictional world-view, albeit using irony as a counterstructure. Their heroines are in various ways overdetermined, and their role as tragic protagonist differentially displaced, either because the heroinic role is divided between different women with polarized claims to heroinism, (Francie and Charlotte in The Real Charlotte; Susan and Slaney in The Silver Fox) or because it is divided between different tragic modes, the classical one, and a more archaic, pre-tragic one, or because irony is used to displace and avert the tragic, by the operations of a Teiresias-like figure who, in the more modernist case of Sarah's Youth, arrives, untypically, in time to avert catastrophe. One of the major topoi of tragedy is knowledge that arrives too late, or is misheard by the hero. Somerville and Ross engage the pre-tragic structure of archaic myth, in this case the ancient Irish seer-figure, who is Teiresias-like in having instinctive access to modes of understanding beyond the divisions and power-hierarchies of sex, class and culture group. Such agencies appear in all three novels; Norry in The Real Charlotte, both Slaney Morris and Maria Quin in The Silver Fox, and Sarah's half sister Kathleen in Sarah's Youth. In the latter two cases, the covert knowledge does arrive in time, is heard by the heroine, and so disaster is averted at least for some. It is difficult to see redemption for any of the principal characters in the first case. One aspect of the modernism of Sarah's Youth may be that personal tragedy triggered by emotional rivalries might seem a disaster less threatening in the inter-war period when a clearer sense of cataclysm was present in the global rumour.

Somerville and Ross's tragic vision references Ireland's past, and their tragic rhetoric has resonance with world literature, and Greek tragedy in particular. Their all-pervasive irony, present at comic, realist and tragic moments in their fictions, places them firmly in an Irish tradition. I have argued elsewhere (Ryan 2004 II) that Ireland's rich novelistic tradition has relatively few examples, in European terms, of the Catholic intellectual novel, a counterexample being Kate O'Brien. Somerville might indeed be compared to George Sand, another 'uppity woman' whose artistic achievement has also been somewhat belied by overemphasis on her lifestyle. Somerville and Ross also cover a range of literary, artistic and cultural expression. Their satire is placed in an Irish tradition: Swift, Joyce, contemporary authors like Roddy Doyle. Their portrayal of Hiberno-English, not a 
politically unproblematic category even today, is one example of how Irish literature came to be seen as more than part of English Literature. This underlies Kiberd's citing of The Silver Fox. It seems arguable that ever greater prominence should be given, in the twenty-first century, in a way difficult for the twentieth century in which the Irish state was founded, to the part played by Somerville and Ross in inventing Ireland.

\section{REFERENCES}

Aristotle.1932. [4 ${ }^{\text {th }}$ c. BCE]), Aristotle in 23 Volumes: Poetics vol. 23, Tr W.H. Fyfe, Cambridge, MA: Harvard University Press; London, William Heinemann Ltd [The Annenberg Project: Perseus].

Compagnon, Antoine.1979. La Seconde main. Paris: Seuil. .1993. L'Esprit de l'Europe vol. 3 Goûts et manières, Paris : Flammarion.

de Vere White, Terence .1977. Review of The Real Charlotte, in Somerville \& Ross, The Real Charlotte, London: Quartet: $4^{\text {th }}$ p. cover.

Kiberd, Declan.1995. Inventing Ireland, London: Jonathan Cape.

Kristeva, Julia.1974. La Révolution du langage poétique. Paris: Seuil.

Ryan, Angela.1992. "Kathleen Ni Houlihan and her Discontents: The Heroine in Anglo-Irish Drama", Alizés, 4 (October), 21-46. .1994. "The Transformation of the Body: Phèdre and Monique", Paragraph, (March), 81-91.

2003. «Corps d'origine, pêché originel: sources antiques de la voix tragique », in D. Sabbah et P. Feyler, eds., L'Origine des texts: Eidôlon, 63 (mai), 279-290.

2004a. "The Lost Heroine and the Memetics of Cultural Inscription in Euripides' Hippolytus and Racine's

Phèdre", in Graham Gargett, ed., Heroism and Passion in Literature: Studies in Honour of Moya Longstaffe, Amsterdam: Rodopi, 40-55.

2004b. “'A Franco-Irish Solution?' Francois Mauriac, Kate O'Brien and the Catholic Intellectual Novel”,

in E. Maher and G. Neville, eds., France and Ireland: Anatomy of a Relationship, Frankfurt: Peter Lang, 97-109.

Somerville, Edith Oenone \& Martin Ross (1894), The Real Charlotte, London: Ward and Downey Ltd (3 vol.). 1899. Some Experiences of an Irish R.M., London: Longmans, Green and Co.

1904. The Silver Fox, London: Longmans, Green and Co. [1998: London: Messrs Lawrence and Bullen

Ltd. Transferred]. .1908. Further Experiences of an Irish R.M., London: Longmans, Green and Co. 1915. In Mr. Knox's Country, London: Longmans, Green and Co. .1928. French Leave, London: William Heinemann. 1938. Sarah's Youth, London: Longmans, Green and Co. 